\title{
REPRISES: CHRIS GREGORY'S GIFTS AND COMMODITIES AND THE FRONTIER
}

\begin{abstract}
Chris Gregory's Gifts and Commodities (1982) is widely regarded as a classic in economic anthropology as well as in studies on Melanesia. The work offers a lucid typology and definition of the concepts of 'gift' and 'commodity' based on the tradition of political economy and economic anthropology. It shows how in colonial Papua New Guinea (PNG) gift and commodity economies articulated with each other and-contrary to the assumption of neoclassical economists-expanded simultaneously. In recounting how labour and primary production were commodified in colonial PNG, Gregory analyses the development and demise of the plantation economy and utilizes the concept of the 'labour frontier' that moved to new areas and eventually closed leading to the crisis of the plantation sector. In this essay I will briefly discuss Gregory's notion of the 'labour frontier', relate it to later theorizations of the concept of 'frontier' and discuss how Gregory's accounts helped me to understand contemporary dynamics of oil palm development in contemporary PNG.
\end{abstract}

\section{INTRODUCTION ${ }^{1}$}

Chris Gregory's book Gifts and Commodities (1982) is remembered for its very clear, neat and useful typology and comparison of the concepts of 'gift' and 'commodity' in political economic terms and for the analysis on how 'gift economies' and the 'commodity economy' articulated with each other in colonial Papua New Guinea (PNG). When starting my graduate studies on questions of land use and natural resource extraction in PNG, I too read Gifts and Commodities and was impressed by the definitions of 'gift' and 'commodity' as historically specific concepts in the tradition of political economy and economic anthropology. Moreover, the book seemed, and still seems, to me to offer a decisive blow to the explanatory power of neoclassical models of non-capitalist economies.

The book remained for me in the background, a work that set the foundation for the concepts and which offered a neat model of gift and commodity relations in colonial PNG, but with which I did not engage further. Much later, when finishing my $\mathrm{PhD}$, I gave a conference paper on oil palm plantations, the history of plantation agriculture and the concept of the 'frontier' in relation to natural resource extraction in PNG. Matti Eräsaari who was in the audience reminded me that Gifts and Commodities deals with the historical development of the plantation economy in PNG in relation to what Gregory calls the 'labour frontier', a new area of labour supply and where people were often made to work 
using force (Gregory 1982: 119). I returned to the book and realized that Gregory's account of the political economic processes of the procurement of cheap labour from new areas and the following rising costs of labour not only preceded contemporary theorizations of the frontier concept, but helped me to understand the re-emergence of plantation production in the rural Pomio Distrcit in PNG.

When Andrew Graan introduced this essay series called 'Reprises' in which scholars revisit older works from new angles, I wanted to contribute, as re-reading Gifts and Commodities opened up new intellectual frontiers, so to say, for me. In this essay I will briefly go over the main arguments of Gregory's book and discuss especially his use of the concept of 'labour frontier', which I will relate to contemporary theories of 'frontiers' in the anthropology of globalization, political ecology and peasant studies. Finally, I will show how knowing the newer discussions, Gregory's account of the shifting, and eventually closing, labour frontier in PNG helped me to identify processes at play in the establishing of new oil palm plantations under frontier conditions in the Pomio District of New Britain Island, PNG.

\section{GIFTS AND COMMODITIES}

As Gregory (1982: ix) notes in the Preface to his work, the impetus to write it came to himprior to his training as an anthropologist-while teaching economics at the University of Papua New Guinea in 1973-1975, traveling around the country and seeing the local economy, or economies, in action. This led him to 'lose what little faith [he] had in the explanatory powers of orthodox economic theory' and turn to the ethnographic literature on PNG (Gregory 1982: ix).

In Gifts and Commodities Gregory set out to show that the ahistorical models of neoclassical economics were not able to adequately conceptualize the indigenous gift economies of PNG and thus failed to understand the economic realities of colonial PNG. In short, neoclassical economics based on ahistorical assumptions of a universal economic system and the imposition of capitalist categories regardless of context assumed that the 'backward', 'subsistence producing' and 'inefficient' traditional economy would be replaced by the 'dynamic', 'modern' and 'efficient' colonising economy (Gregory 1982: 105, 155). This however did not happen, and the gift economies of PNG 'effloresced'. The gift economies were definitely indigenous, but not 'traditional' as opposed to a 'modern' commodity economy in the dualist conception of the neoclassical economists, but two parts of a single and modern economy, where the production of commodities and gifts had risen simultaneously (Gregory 1982: 4-5, 112, 115). The gift economy of colonial PNG was thus not a relic, but in its intensified form a response to the contemporary conditions and where things were either gifts or commodities, where commodities turned into gifts and vice versa depending on the social context (Gregory 1982: 115-16).

In order to offer a better explanation, Gregory (1982: 12-13) defines and distinguishes 'gifts' and 'commodities' embedded within the social and political relations. To put it extremely briefly and simply, commodity exchange is about alienable objects exchanged between reciprocally independent people that creates quantitative relations between the things exchanged, whereas in gift exchanges reciprocally dependent people exchange inalienable objects creating qualitative relations between the people exchanging (Gregory 1982: 19, 100). More so, in order to understand which forms things and labour in a particular context take, one must understand the historically specific situation of how the means 
of production between people are distributed (Gregory 1982:100). While this account is very schematic, with gifts and commodities positioned as virtual inversions of each other, the model is abstracted from empirical research, primarily that of anthropologists.

More so, in the rest of the work Gregory shows the model at work in the 'ambiguous' economy of colonial PNG, where things are gifts and commodities depending on the context. Again, to simplify Gregory's nuanced analysis, the colonial economy commodified primary production, such as agriculture and mining, as well as labour, but did not eradicate the gift economies. A key reason for this was that despite land grabs and land alienated for plantations, to a large extent land in PNG was not alienated or commodified, and thus the material basis of the gift economies was retained (Gregory 1982: 116-17). Commodity production intensified the gift economies, in which commodities were turned into gifts, and at the same time, the gift economy had to intensify, in order to retain clan control over land and to thereby resist its commodification (Gregory 1982: 117, 165). And conversely, the indigenous gift economies, for their part subsidized the commodity economy, as they reproduced the labour force (Gregory 1982: 143).

\section{THE LABOUR FRONTIER}

In order to examine the relationship between the 'ambiguous' economy of colonial PNG and the articulation between the gift and commodity economies, Gregory turns to the rise of plantation labour during the early colonial period, which lasted from 1884 to 1975 . In the plantation sector, socially reproductive labour, which in the indigenous societies took the form of 'gifts', was appropriated and transformed into a commodity in the labour time of the plantation workers (Gregory 1982: 143). The colonists, Britain and Germany, who partitioned what later became PNG in 1884, and finally from 1914 to 1975, Australia, were after the natural resources and the labour of local men. However, as local people had no established need to sell their labour time, the need had to be created in order for labour to become a commodity (Gregory 1982: 118). With the concept of the 'labour frontier', Gregory (1982: 119) describes the process through which new areas were opened as supplies of cheap labour, often initially through the use of force.

This was a long, drawn-out and often violent process that started in the Island region of current PNG comprising the Bismarck archipelago and north-eastern Solomons with forced overseas indentured labour (1863-1904), continued as semi-forced domestic indentured labour (1963-1950), semi-free or agreement labour (1951-1974) finally free labour (1927-) (Gregory 1982: 118). In this process, the local people were in various ways forced to work on plantations, first through cheating and outright coercion during the 'Pacific labour trade' era when Melanesians were recruited as cheap labour for plantations on Queensland and Samoa and later through the imposition of taxes payable only in government money (Gregory 1982: 119, 153). After people became more experienced with plantation labour and demanded more pay, when they shifted to the production of cash crops or when the colonial government restricted recruiting of labour in over-recruited areas, cheap labour had to be procured elsewhere (Gregory 1982:118, 131,146). This colonial dynamic by which Melanesians were forced to alienate their labor on plantations illustrates what Gregory dubs the 'labor frontier'. A colonial infrastructure of agricultural production, tax administration and trickery served to transform socially 
reproductive labor into a commodity within the planation system and other sectors of colonial primary production, like mining.

Gregory's conceptualization of the labour frontier thus emphasizes how labor is only commodified under specific conditions and these conditions may well shift, resulting in new political economic formations. This dynamic of the opening, closing and shifting of the labour frontier is well illustrated by Pomio District, a rural area of New Britain Island, where I conducted research on land use changes, the expansion of logging and industrial agriculture. New Britain Island was the first labour frontier and also among the first to close (Gregory 1982: 129). The labour frontier was opened in Pomio before the colonial era when labour recruiters raided the area in the 1870s and 1880s for labour for plantations on Queensland and Samoa (Laufer 1955: 33; Panoff 1969:111). When Britain and Germany partitioned New Guinea in 1884, New Britain fell under German rule. Initially the German areas were ruled by a trading company, the German New Guinea Company (NGC), which established plantations on New Britain and especially mainland New Guinea. As mainlanders were unwilling to work on them, the trading company recruited labour from the Islands, where people had more experience of indentured labour. The conditions were abysmal: the annual death-rate of the workers who passed through the Kokopo recruiting station was 40\% between 1887-1903 (Firth 1976:52-53). This obviously decreased the appeal of plantation employment and attacks on recruiters increased while the number of labourers on the mainland decreased. At the same time, the Gazelle Peninsula in New Britain became a much more popular destination among labourers from the Islands, as conditions were healthier and it was closer to home for many labourers (Firth 1976: 53).
The attempt to rule the colonies through the trading company quickly failed and in 1899 the German imperial administration took over. As most New Guineans were quite independent and took on labour when it suited them, the administration was faced with a labour shortage (Dennis [1980]:228; Firth 1976: 54). Under the NGC labour recruitment had resembled the Pacific labour trade as it was based, at least in theory, on mutual consent. The imperial administration wanted to change this and forced labour mobilization became its special task (Firth 1976: 52, 54-56; Gründner 1985: 171). Under Australian rule, which began after the First World War, the indenture system continued in the same way as under the Germans (Fitzpatrick 1980: 78). According to Peter Fitzpatrick (1980: 77), despite Australia's reputation as a 'good' colonist, it acted very much like any other, and emphasized the maintenance of cheap labour through labour laws and regulations (see also Kituai 1998: 14-16). This was enforced by criminal penalties for labourers 'deserting' their work or anyone harboring a deserter (Fitzpatrick 1980: 78-80). While Australia sought to preserve 'traditional societies' and even banned labour recruitment in some areas, labour laws initially sought to ensure that the locals remain workers rather than cashcroppers (Dennis [1980]: 232; Fitzpatrick 1980: 78-79, 83).

These were all policies that upheld the 'labour frontier' by keeping people as a labour reserve and making sure that the local societies reproduce the labour. The penal sanctions were lifted in the 1950s (Fitzpatrick 1980: 80) and, as Gregory $(1982: 146,155)$ notes, former indentured and agreement labourers became smallholders and primary producers and no longer signed up as workers, contributing to the closure of the labour frontier. During my fieldwork, a Pomio man, who had been active 
in establishing a village co-operative society for the buying and selling of cash crops, then copra, noted that without the penal policies and the discouragement of local cash cropping people would not have worked on the plantations. In Pomio, the labour frontier began to close in the 1950s. According to a colonial official, there was 'gross over-recruiting' in certain communities in Pomio, with up to a half of the able bodied men absent (Patrol report: Bell 1950). Similarly, in a patrol report from 1956, the patrol officer mentions how the Baining and Sulka speakers of Pomio 'loath' to work for long periods on plantations and returned quickly, leading plantation owners to rely on labour from other areas (Patrol report: Hearne 1956)—clearly illustrating the dynamics of the shifting labour frontier.

New Britain, which was the first labour frontier to open, became the leader in smallholder commodity production and thus the first labour frontier to close. This was so especially in the areas around the provincial capital of Kokopo and in the Gazelle peninsula. In more remote areas, like Pomio, the frontier closed somewhat later. As noted, cheap labour for plantations was then procured from other areas, until the Highlands, which was the last labour frontier to open in the 1950s, closed, as Highlanders began to cash cropping leading ultimately to the crisis of the plantation sector and exit of plantation capital in the 1970s. (Gregory 1982: 131, 157).

\section{FRONTIER DYNAMICS IN CONTEMPORARY POMIO}

In Gregory's analysis of the history of the plantation sector in colonial PNG the 'labour frontier' is first and foremost a spatio-temporal dynamic in the establishment and expansion of the commodity economy. Gregory shows how labour as a commodity did not simply exist in the indigenous economies of PNG, but the conditions of its emergence had to be manufactured. Interestingly, Gregory's approach to the labour frontier converges with how contemporary scholars working in political ecology and peasant studies have theorized frontiers in relation to ongoing processes of land grabbing and commodification of labour and natural resources. These studies draw attention to the creation of commodities through the reframing and revaluation of environments. This revaluation often involves presenting the areas as 'empty' or 'unused' wilderness, thereby ignoring local meanings and patterns of use (Eilenberg 2014: 160; Stella 2007: 3, 49, 51; Tsing 2005: 32). As Alice Kelly and Nancy Peluso note (2014: 475) new frontiers of capitalist expansion are not so much newly discovered places, but sites of new commodity forms. The places become frontiers when changes in political economy reconstitute the relations between capital, society and state authorities (Kelly and Peluso 2014: 475). Natural resources, then, are always both natural and social, that is, products of contingent sociocultural definitions. (McCarthy 2013: 184; also Bridge 2011: 820). As Jason Moore (2015: 145) notes: coal is coal, but it is fossil fuel only under very specific historical and social conditions. The same goes for labour or other natural resources.

Even though the labour frontier closed in New Britain relatively early, Pomio District remained marginal within the political and economic structures of the province and the country, as the district is sparsely populated, has lacking services and infrastructure (see for example Allen 2009: 486; Tammisto 2018: 3-6). This marginality created the conditions for frontiers to open again. John McCarthy (2013) defines the frontier is a physical place in rapid transformation, where population density tends to be low, the rate of in-migration usually high 
and organs of the central state weak, meaning that the law is an abstract concept. In this context natural resources are up for grabs, so to speak (Tsing 2005:17), and different actors compete to establish claims over them (McCarthy 2013: 183). Furthermore, on the frontier different actors do not only compete over resources, but over varying definitions of what constitutes a natural resource. Meanwhile, when different actors assert claims over resources, they are also advancing different definitions of the value of local environments, local practices and different forms of land tenure (McCarthy 2013: 184). Pomio became such a frontier especially in terms of natural resources and later, once again, in labour.

McCarthy's (2013) definition of a frontier differs from Gregory's concept of the labour frontier, in as much Gregory focuses on labour and the spatio-temporal processes of its commodification, while McCarthy focuses statecontrol, territorialization and the revaluation of environments as resources. However, there are important underlying similarities between Gregory's concept of the 'labour frontier' and later uses of the concept of 'frontier' by Eilenberg (2014), McCarthy (2013), Kelly and Peluso (2014), Li (2014) and Moore (2015) for instance. All of the accounts focus on how human lives and environments are revalued as commodities and made available for extraction. While Gregory focuses specifically on labour, the other accounts deal more broadly with commodifcation and the making of resources. All the analyses share, more or less explicitly, the focus on temporal aspect of frontiers, namely that frontiers are 'time windows', during which resources seem abundant and 'up for grabs' and do not last forever, but close and are opened up elsewhere. Taken together, they help us understand how people's lives and environments are commodified and made available for extraction in places such as Pomio.

Like elsewhere in PNG, household production of cash cropping diminished with the decline of buying infrastructure in the 1980s and 199s (Allen 2009: 296). As Pomio was not connected by roads to larger centers, copra ships visited the rural areas and bought produce from the local smallholders, but since the mid1990s they stopped and the smallholders had to arrange the transport themselves-diminishing their returns. Large-scale logging began in Pomio, much like elsewhere in PNG, in the late 1980s and early 1990s, when PNG became a resource frontier for foreign logging companies. Frontier conditions emerged as a combination of several processes: the state of PNG needed revenue with the decline of the plantation sector and the closing of the Panguna mine in Bougainville (Gregory 1982: 135-137; May 2001:313-315, 317, 321); at the same time, infrastructure in rural areas was deteriorating and the income of many rural cash-croppers decreasing due to transport difficulties and declining prices for agricultural commodities. The state of PNG was thus eager to grant logging concessions (Bell 2015: 137), while many locals hoped to access infrastructure, income and services in exchange for their forests (Leedom 1997: 44; May 2001: 321; Simpson 1997: 24). This opened PNG to foreign logging companies at a time when Malaysian logging companies were looking to move on to new territories because of the ban on logging in Sabah and Sarawak (Filer 1998: 57, 60).

In the beginning of the 2000s, local politicians initiated large-scale combined logging and agriculture projects in order to bring income, services and infrastructure to Pomio district (Tammisto 2010; 2016). The plan was that foreign logging and oil palm companies connect 
the logging roads established in Pomio during the 1990s with provincial road network around Kokopo in exchange for logging concessions and land leased for plantations. In 2008, a new oil palm plantation was established by a Malaysian company in East Pomio on state land alienated during the colonial era and on land leased from the customary owners (Tammisto 2016). Under PNG legislation land under customary tenure cannot be alienated and due to unsustainable logging in the 1990s, the export of raw logs was restricted. The reinterpretation of land lease legislation however re-opened the land and logging frontiers: between 2003-2011 up to $11 \%$ of PNGs land area was leased under long-term agricultural leases, often to private companies (Filer 2011: 599).

In Pomio the oil palm companies had then access to two prerequisites of the plantation mode of production: cheap land and cheap labour (Dennis [1980]: 219), because with the diminishing returns from cash-cropping due to falling agricultural commodity prices, high transport costs and in the case of cocoa, blights, many inhabitants of Pomio needed the income from labour. In Pomio, the processes which initially closed the labour frontier, partial overrecruitment and especially the shift to cashcropping, were thus reversed and this created the conditions for the labour frontier to open again. And as in the colonial era, the rural communities subsidized the plantations, in as much plantation workers from Pomio cultivated their own food on plantations or were sent food from their home villages allowing the workers from Pomio work at relatively low wages (Tammisto 2018: 148-50).

\section{CONCLUSION}

Even though not often remembered for the discussion of 'the frontier', with Gifts and
Commodities Gregory has provided an important contribution to the discussion. In line with later developments of the concept, in Gregory's usage the frontier is not simply a place, but a particular political economic dynamic in the commodification of things and especially of the labour of Papua New Guineans in the colonial era. In Gifts and Commodities it is based on the theoretical tradition of political economy and robust empirical data, namely archival material on labour recruitment that shows how the labour frontier opens and closes in a certain place, moves to another and eventually seizes to exist due to different processes-for example labourers preferring to become smallholders and primary commodity producers.

Particularly this temporal aspect is an important precedent for later studies that develop the concept. For example, Tania $\mathrm{Li}$ (2014) shows how the 'land frontier' in the Sumatra Highlands closed quickly and before people realized, they were left landless as they could not clear further areas inland. New frontiers are also not just, or even foremostly, about 'discovering' new places, but about new commodity forms that become available due to political economic changes that reconstitute relations between people, capital and state authorities, as Alice Kelly and Nancy Peluso (2014: 475) note. These changes can lead to the re-opening of old frontiers, and as Michael Eilenberg (2014) frontier dynamics may be cyclical. Gregory's concept of the 'frontier' not only precedes contemporary theories, but in focusing on one particular commodity, labour, and detailed archival and empirical data, such the number of labourers and the price of labour, the concept is for Gregory not only a metaphor, but a concept that arises out of the material. It offers thus also a model of how to study frontier dynamics.

As I have briefly noted above, this is what 
happened in Pomio, where the labour frontier reopened, partly because of the reversal of the processes that led to its closure as described by Gregory. As returns from cash cropping declined, at least in certain areas of Pomio, taking on wage labour on plantations seemed more lucrative. For logging and oil palm companies Pomio was until very recently a frontier, as newly found legal mechanisms opened the land and forest frontiers. It will be seen how long these frontier conditions last and for example how widely cheap labour necessary for the plantations is available, or do the plantation companies need to search for labour on new frontiers.

This essay series is about re-discovering scholarly works in new ways, focusing on less-discussed aspects of a canonical work or focusing on works that for different reasons have remained in the margins or marginalized. Gifts and Commodities certainly is not a marginal book, although prior to the second edition in 2015 , the original 1982 was occasionally hard to get hold of. On the contrary, the book earned itself an established position in the discipline. The typology, models and account that Gregory developed are what most readers engaged with and probably will continue to do so, for good reasons. In this essay I have focused on the 'labour frontier', which decidedly is one 'side show' of the book and a concept that merely supports the larger argument. However, as I have attempted to show, because it is based on careful theoretization and empirical material, it brings to light some general features of frontiers and frontier conditions and explain certain key dynamics in the history of the commodity economy in Papua New Guinea. Sometimes what the author has not emphasized may be an important gift to others.

\section{NOTES}

1 I want to thank Matti Eräsaari, Anu Lounela, Timo Kaartinen, Mira Käkönen, Markus Kröger, Jenni Mölkänen, Liina-Maija Quist and especially Andy Graan for his comments to this essay. I wrote it in the project New regimes of commodification E' state formation on the resource frontier of Southeast Asia funded by the Kone Foundation. My research in Pomio in 2007, 2011-2012, 2014 and 2019 would not have been possible without the help and hospitality of the Mengen communities. It is to them I owe my greatest gratitude.

\section{REFERENCES}

Allen, Bryant 2009. Agricultural Development, Policies and Governance. In Michael Bourke and Tracy Harwood (eds). Food and Agriculture in Papua New Guinea. Canberra: Australian National University.

Bell, Joshua 2015. The Structural Violence of Resource Extraction in the Purari Delta. In Joshua Bell, Paige West, and Colin Filer (eds). Tropical Forests of Oceania: Anthropological Perspectives. Canberra: ANU Press.

Bell, R.S. 1950. Patrol Report No. 11 of 1949/1950 Gasmata 24.1.1950-22.2.1950; 1.3.1950-10.5.1950. East New Britain District, Pomio 1948-1950. National Archives of Papua New Guinea, Accession 496. http://library.ucsd.edu/dc/object/bb1810781r. <accessed 20 May 2016>

Bridge, Gavin 2011. Resource Geographies I: Making Carbon Economies, Old and New. Progress in Human Geography 35 (6): 820-34. https://doi.org/10.1177/0309132510385524.

Dennis, Maxine [ca. 1980]. Plantations. In Donald Denoon and Catherine Snowden (eds). A Time to Plant and a Time to Uproot: A History of Agriculture in Papua New Guinea. [Papua New Guinea]: Institute for Papua New Guinea Studies.

Eilenberg, Michael 2014. Frontier Constellations: Agrarian Expansion and Sovereignty on the Indonesian-Malaysian Border. The Journal of Peasant Studies 41 (2): 157-82.

https://doi.org/10.1080/03066150.2014.885433. 
Filer, Colin with Nikhil Sekhran 1998. Loggers, Donors And Resource Owners. London: IIED.

Filer, Colin 2011. The Political Construction of a Land Grab in Papua New Guinea. Resources, Environment and Development. Pacific Discussion Paper 1. Canberra: Australian National University.

Firth, Stewart 1972. The New Guinea Company, 1885-1899: A Case of Unprofitable Imperialism. Historical Studies 15 (59): 361-77.

https://doi.org/10.1080/10314617208595478.

Firth, Stewart 1976. The Transformation of the Labour Trade In German New Guinea, 1899-1914. The Journal of Pacific History 11 (1): 51-65.

Fitzpatrick, Peter 1980. Really Rather like Slavery: Law and labour in the Colonial Economy in Papua New Guinea. Contemporary Crises 4 (1): 77-95. https://doi.org/10.1007/BF00728316.

Gregory, Chris 1982. Gifts and Commodities. London: Academic Press.

Gründner, Horst 1985. Geschichte der deutschen Kolonien. Padeborn: Schöningh.

Hearne, R.F. 1956. Patrol Report No. I of 1956/1957, Wide Bay 14.8.1956-30.8.1956. East New Britain District, Kokopo, 1956-1957. National Archives of Papua New Guinea, Accession 496. http://library.ucsd.edu/dc/object/bb2459147d. <accessed 20 May 2016>

Kelly, Alice and Nancy Peluso 2014. Frontiers of Commodification: State Lands and their Formalization. Society \& Natural Resources: An International Journal 28 (5): 473-95.

https://doi.org/10.1080/08941920.2015.1014602.

Kituai, August Ibrum 1998. My Gun, My Brother: The World of the Papua New Guinea Colonial Police 1920-1960. Honolulul: University of Hawai'i Press.

Laufer, Carl 1955. Aus Geschichte und Religion der Sulka. Anthropos 50 (1-3): 32-64.

Leedom, John 1997. Private Dealings: A Social History of the Hawain Local Forest Area, East Sepik Province. In Colin Filer (ed.) The Political Economy of Forest Management in Papua New Guinea. Boroko: National Research Institute.

Li, Tania 2014. Land's End: Capitalist Relations on an Indigenous Frontier. Durham: Duke University Press.
May, Ronald 2001. State and Society in Papua New Guinea: The First Twenty-Five Years. Canberra: Australian National University.

McCarthy, John 2013. Tenure and Transformation in Central Kalimantan: After the 'Million Hectare' Project. In Anton Lucas and Carol Warren (eds). Land for the People: The State and Agrarian Conflict in Indonesia. Athens: Ohio University Press.

Moore, Jason 2015. Capitalism in the Web of Life: Ecology and the Accumulation of Capital. New York: Verso Books.

Panoff, Michel 1969. An Experiment in Inter-tribal Contacts: The Maenge Labourers on European Plantations 1915-42. The Journal of Pacific History 4 (1): 111-125.

Simpson, Gary 1997. 'Get What You Can While You Can': The Landowner-Government Relationship in West New Britain. In Colin Filer (ed.) The Political Economy of Forest Management in Papua Nerw Guinea. Boroko: National Research Institute.

Stella, Regis 2007. Imagining the Other: The Representation of the Papua New Guinean Subject. Honolulu: University of Hawai'i Press.

Tammisto, Tuomas 2010. Strengthening the State: Logging and Neoliberal Politics in East New Britain, Papua New Guinea. Suomen Antropologi: Journal of the Finnish Anthropological Society 35 (1): 43-59.

Tammisto, Tuomas 2016. Enacting the Absent State: State-formation on the Oil-palm Frontier of Pomio (Papua New Guinea). Paideuma: Mitteilungen zur Kulturkunde 62: 51-68.

Tammisto, Tuomas 2018. New Actors, Historic Landscapes: The Making of a Frontier Place In Papua New Guinea. $\mathrm{PhD}$ thesis. Helsinki: Unigrafia. https://helda.helsinki.fi/handle/10138/231102. <accessed 8 March 2019>

Tsing, Anna Lowenhaupt 2005. Friction: An Ethnography of Global Connection. Princeton: Princeton University Press.

TUOMAS TAMMISTO

POSTDOC RESEARCHER

SOCIAL AND CULTURAL

ANTHROPOLOGY

UNIVERSITY OF HELSINKI

tuomas.tammisto@helsinki.fi 